\title{
Phase Transformations in NiTi Endodontic Files and Fatigue Resistance
}

\author{
S. Vilaverde Correia ${ }^{\text {a,1,2 }}$, M.T. Nogueira ${ }^{2}$, R.J.C. Silva ${ }^{2}$, L. Pires Lopes ${ }^{1}$, F. M. Braz Fernandes ${ }^{2}$ \\ ${ }^{1}$ Faculdade de Medicina Dentária da Universidade de Lisboa, Cidade Universitária 1649-003 Lisboa, Portugal \\ ${ }^{2}$ CENIMAT/I3N, Faculdade de Ciências e Tecnologia, Universidade Nova de Lisboa, 2829-516 - Monte \\ Caparica, Portugal
}

\begin{abstract}
NiTi endodontic files allow for clinical enlargement of harshly curved root canals. However, files rotated under severe flexion might fracture unexpectedly, remain inside teeth and thus, hinder treatment outcome. ProFile $.06(35)$ are among the most commonly used rotary files. In the present study, 10 of these brand new instruments were used to perform DSC on their cutting regions and determine the amount of R-phase present at $10,20,37$, and $65^{\circ} \mathrm{C}$, both during cooling and heating programmed cycles. Another 48 new ProFile .06(35) instruments underwent rotation/flexion assays at $300 \mathrm{rpm}$ and $10 \mathrm{~mm}$ radius of curvature. Files were divided into four groups of 12 instruments each. Each group was tested at $10,20,37$, and $65^{\circ} \mathrm{C}$. The number of cycles to fracture $\left(\mathrm{N}_{\mathrm{f}}\right)$ and the length of the broken segment $\left(\mathrm{L}_{\mathrm{f}}\right)$ were determined for each tested file. Results show no statistically significance $(\alpha=0,05)$ as for $\mathrm{L}_{\mathrm{f}}$ in all groups. On the contrary, $\mathrm{N}_{\mathrm{f}}$ depends highly on testing temperature: as temperature increases from 10 to $37^{\circ} \mathrm{C}, \mathrm{N}_{\mathrm{f}}$ strikingly decreases; from 37 and $65^{\circ} \mathrm{C}$, no significant changes in $\mathrm{N}_{\mathrm{f}}$ occur. As for DSC results, it is clearly shown that R-phase is most abundant at $10^{\circ} \mathrm{C}$ and consistently decreases up to $37^{\circ} \mathrm{C}$, both during heating and cooling; from 37 to $65^{\circ} \mathrm{C}$, the quantity of R-phase in the alloy is negligible. In conclusion, it is shown that fatigue resistance in ProFile .06(35) instruments is not only highly enhanced but also proportional to the amount of R-phase in the alloy.
\end{abstract}

\section{Background}

Root canal degree of curvature is highly dependent on tooth type [1-3] as canal shape roughly corresponds to its root shape [4]. Endodontic literature agrees on most root canals having some degree of curvature [5]. Stainless steel files produce more canal transportation in curved canals than their Ni-Ti rotary counterparts, both in acrylic simulated root canals [6, 7], and in extracted teeth [8,9]. Dalton et al. [10] showed, in vivo, that Ni-Ti files and stainless steel files are equally effective in reducing intracanalar bacteria when matched for size. However, if more tapered Ni-Ti files are used, then rotary files allow for better irrigation at working length [11, 12] and, hence, for a better apical cleaning. The faster results obtained with Ni-Ti rotary files [13, 14] have also made them increasingly popular among clinicians and their use is now even taught at undergraduate level [15-17].

The major drawback of Ni-Ti instrumentation is file rupture. Iqbal et al. [18] report that the odds for rotary Ni-Ti file breaking were seven times more than for hand stainless steel file separation in graduate clinical setting. Spili et al. [19] report similar findings in a population of experienced endodontists, which accounts for the overall perception among general practitioners that Ni-Ti files break more often than hand stainless steel files [20]. Reliable data on Ni-Ti fragments that remain inside root canals is still scarce. Spili et al. [19] are, so far, the only authors who investigated the influence of retained $\mathrm{Ni}$-Ti fragments on prognosis by means of a case-control study. Although not absolutely conclusive, their findings suggest prognosis might be hindered by clinical persistence of non retrievable Ni-Ti fragments whenever a periapical lesion is present.

The aforementioned possibility justifies the need for a better understanding of rotary Ni-Ti file rupture in order to devise possible methods to increase file fatigue life. Some bench studies [21-24] have been carried out in order to characterize fatigue life of different brands of Ni-Ti endodontic instruments, using prototypes which impose specific radius and angles of curvature on Ni-Ti files [25]. However, all these studies were done at room temperature, whereas $\mathrm{Ni}-\mathrm{Ti}$ instruments are called upon to work at body temperature $\left(37^{\circ} \mathrm{C}\right)$. Some other

\footnotetext{
a-mail: sanchovc@gmail.com
} 
publications [26-30] have investigated transformation temperatures of Ni-Ti alloy from rotary files, suggesting $\mathrm{A}_{\mathrm{f}}$ is close to $37^{\circ} \mathrm{C}$ and, therefore, these instruments are completely austenitic at body temperature.

The aim of this study is to test Ni-Ti files at different temperatures and compare the number of cycles to fracture to the amount of R-phase present at those temperatures, as determined by Differential Scanning Calorimetry (DSC) analysis.

\section{Materials and Methods}

\subsection{D.S.C. assays}

10 brand new $25 \mathrm{~mm}$ ProFile .06(35) files (Maillefer-Dentsply, Switzerland) were used for D.S.C. assays. 10 samples were thus taken from these 10 files' shanks, homogenized for mass and analyzed by means of a Setaram DSC9 $2^{\circledR}$ calorimeter and two stainless steel crucibles: one baring the sample, the other kept empty. Programmed cycle included a cooling phase, from $100{ }^{\circ} \mathrm{C}$ to $-80{ }^{\circ} \mathrm{C}$ at $-7.5^{\circ} \mathrm{C} / \mathrm{min}$, and a heating phase, from $-80{ }^{\circ} \mathrm{C}$ to $100^{\circ} \mathrm{C}$ at $7.5^{\circ} \mathrm{C} / \mathrm{min}$. Room temperature was kept constant $\left(20^{\circ} \mathrm{C}\right)$ during all assays. During each D.S.C. cycle, real sample temperature $\left(\mathrm{T},{ }^{\circ} \mathrm{C}\right)$ and thermal flux per mass unit $(\varphi, \mathrm{mW} / \mathrm{mg})$ were registered. Cooling and heating phases' results were analyzed subsequently in similar way. First, base lines were subtracted from experimental curves using PeakFit utility for OriginPro7 software. Secondly, all values of flux per mass unit as a function of temperature were transferred to Excel. Graphically, total energy mobilized by phase transformation $\left(E_{t}\right)$ is proportional to the area under the curve $\varphi=f(T)$. For each instant value of temperature, Excel was used to calculate the amount of energy mobilized by phase transformation up to that temperature point, as a percentage of $E_{t}$. Namely, percentage of total energy mobilized by phase transformation was determined for the following temperature points: $10^{\circ} \mathrm{C}, 20^{\circ} \mathrm{C}, 37^{\circ} \mathrm{C}$, and $65^{\circ} \mathrm{C}$.

\subsection{Rotation/flexion assays}

48 brand new $25 \mathrm{~mm}$ ProFile .06(35) (Maillefer-Dentsply, Switzerland) were used for rotation/flexion assays and divided in four groups of 12 files each. All files were tested in a prototype based on the one previously described by Gambarini [21] and by Haikel et al. [22] with a major improvement: test temperature could be controlled with $\pm 1{ }^{\circ} \mathrm{C}$ precision by means of a forced water circulation circuit through the test platform (fig. 1). All files were placed in the test platform so that all of them were subjected to $90^{\circ}$ angle of curvature and $10 \mathrm{~mm}$ radius of curvature, as defined by Pruett et al. [25]. Bending was imposed at $1 \mathrm{~mm}$ from file tip in all cases and rotation was carried out at 300 r.p.m. using a 20:1 handpiece (W\&H, Austria) and a TC-Motor 3000 in the presence of lubricant (vaseline). As mentioned, four groups were formed according to the temperature files were tested at: either $10{ }^{\circ} \mathrm{C}, 20^{\circ} \mathrm{C}, 37^{\circ} \mathrm{C}$, or $65^{\circ} \mathrm{C}$.

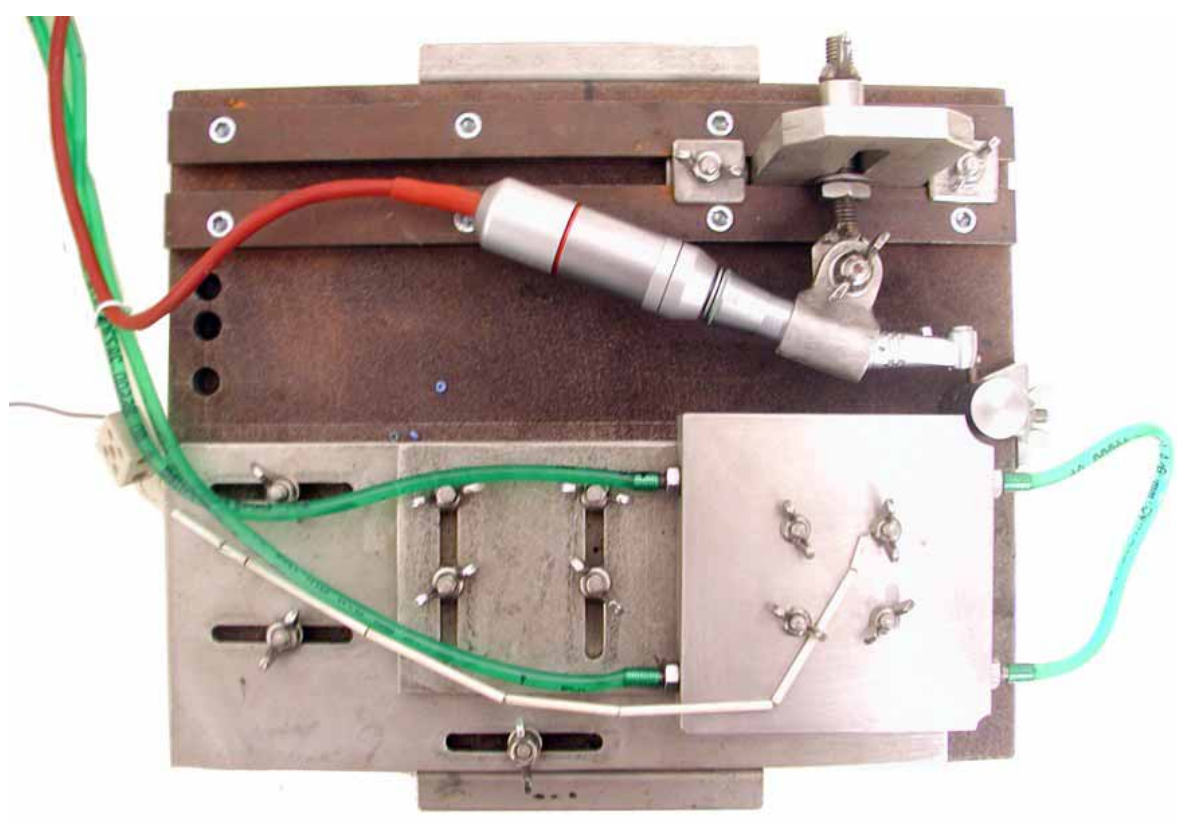

Fig. 1. Prototype for rotation/flexion assays 
For each file, the full procedure from beginning of rotation to file fracture, was recorded with a digital camera (Panasonic NV-GS 400) set on macro mode and mounted on a tripod so that files could be observed at a straight angle from their flexion plane. Pinnacle Studio (v. 12.1) software was used to identify time points of rotation beginning and fracture and therefore determine time needed for fracture to happen with a $\pm 1 / 12 \mathrm{~s}$ precision. The number of cycles $\left(\mathrm{N}_{\mathrm{f}}\right)$ to fracture was then calculated. The length $\left(\mathrm{L}_{\mathrm{f}}\right)$ from tip to fracture site was measured with a caliper (precision $\pm 0,05 \mathrm{~mm}$ ) for all 48 fragments obtained.

Statistical analysis to compare $\mathrm{N}_{\mathrm{f}}$ and $\mathrm{L}_{\mathrm{f}}$ among groups was performed using GraphPad Prism version 5.00 for Windows (GraphPad Software, USA). Distribution of the two variables was checked for normality by means of D'Agostino and Pearson Normality test. One-way ANOVA was used to identify significant differences among groups and, whenever a significant difference was detected, Tukey-Kramer post-hoc tests for multiple comparisons further detailed the results. In all cases, significance level was set at $5 \%(\alpha=0,05)$ and a minimum power of $80 \%[(1-\beta)=0,80]$ was accepted.

\section{Results}

\subsection{D.S.C. assays}

Table 1 summarizes D.S.C. results. During cooling, R-phase is formed as temperature falls below $37^{\circ} \mathrm{C}-$ from an average of $2.0 \%$ at $20{ }^{\circ} \mathrm{C}$ to an average of $30.8 \%$ at $10{ }^{\circ} \mathrm{C}$. During heating, the opposite happens: on average, $58.2 \%$ of R-phase is still present at $10{ }^{\circ} \mathrm{C}$ but only $0.7 \%$ at $37{ }^{\circ} \mathrm{C}$. Figure $2 \mathrm{a}$ shows linear regression of percentage of R-phase present in the alloy upon cooling, with R-phase clearly forming at a lower temperature than $37^{\circ} \mathrm{C}$. As for Figure $2 \mathrm{~b}$, it shows linear regression of percentage of R-phase present in the alloy upon heating. R-phase progressively disappears and it is almost inexistent at $37^{\circ} \mathrm{C}$.

Table 1. Percentage of R-phase present at different temperatures

\begin{tabular}{|c|c|c|c|c|}
\hline & \multicolumn{4}{|c|}{$\begin{array}{l}\text { Percentage of R-phase } \\
\text { Formed during cooling / Still present during heating }\end{array}$} \\
\hline & $10^{\circ} \mathrm{C}$ & $20^{\circ} \mathrm{C}$ & $37^{\circ} \mathrm{C}$ & $65^{\circ} \mathrm{C}$ \\
\hline $\mathrm{n}$ & 10 & 10 & 10 & 10 \\
\hline Min. & $25.81 / 52.39$ & $1.12 / 10.87$ & $0.01 / 0.37$ & $0.00 / 0.00$ \\
\hline Max. & $37.81 / 69.28$ & $3.46 / 17.23$ & $0.39 / 0.83$ & $0.06 / 0.18$ \\
\hline Average & $30.83 / 58.18$ & $1.99 / 12.31$ & $0.14 / 0.66$ & $0.03 / 0.13$ \\
\hline St. Dev. & 4.24 / 4.52 & $0.77 / 1.84$ & $0.10 / 0.14$ & $0.02 / 0.05$ \\
\hline
\end{tabular}

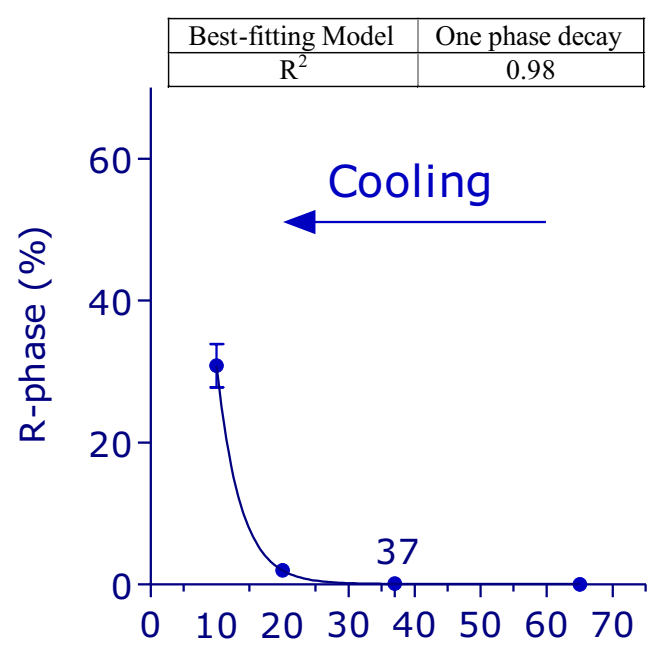

$\mathrm{T}\left({ }^{\circ} \mathrm{C}\right)$

a) Cooling

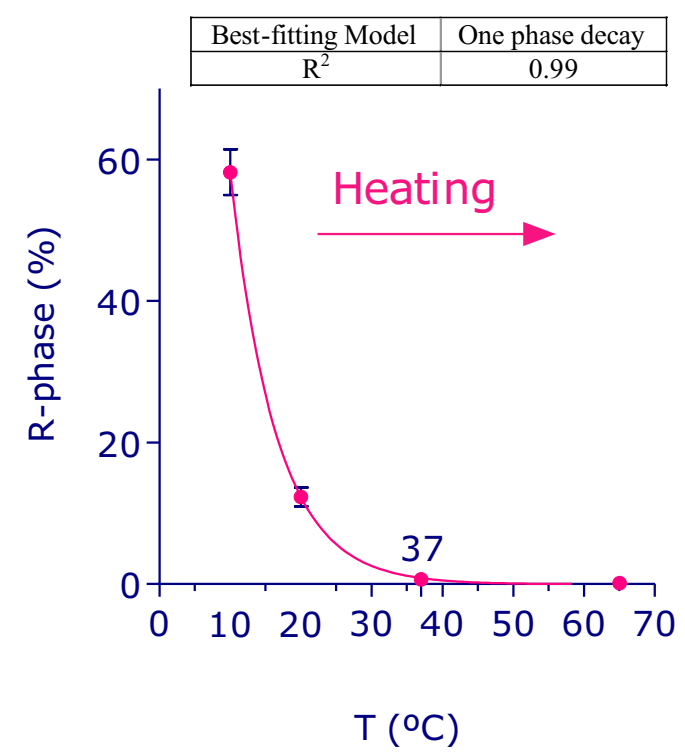

b) Heating

Fig. 2. Non linear regression of Percentage of R-phase as a function of temperature 


\subsection{Rotation/flexion assays}

Table 3 summarizes rotation/flexion assays' results. One-way ANOVA ( $n=48, \alpha=0,05)$ shows no significant differences among groups $(\mathrm{p}=0,94)$ as for location of fracture, which happens on average at $12 \mathrm{~mm}$ from file tip.

As for the average number of cycles to fracture, it varies in an extremely significant way with test temperature (one-way ANOVA, $\mathrm{n}=48, \mathrm{p}<0.0001$ ). Tukey-Kramer post-tests compared groups two by two. Extremely significant differences were found between $\mathrm{N}_{\mathrm{f}}$ at $10{ }^{\circ} \mathrm{C}(2235$ rotations $)$ and $\mathrm{N}_{\mathrm{f}}$ determined for any of the other three test temperatures (Tukey-Kramer post hoc test, $n=24, p<0.001$ ). The number of rotations to fracture at $20^{\circ} \mathrm{C}$ (1498 cycles) differs very significantly from $\mathrm{N}_{\mathrm{f}}$ found at either $37^{\circ} \mathrm{C}$ or $65^{\circ} \mathrm{C}$ (Tukey-Kramer post hoc test, $\mathrm{n}=24,0.001 \leq \mathrm{p}<0.01)$. As for the averages of $\mathrm{N}_{\mathrm{f}}$ found at $37^{\circ} \mathrm{C}(960$ cycles $)$ and at $65^{\circ} \mathrm{C}(1021$ cycles), they do not differ significantly (Tukey-Kramer post hoc test, $n=24, p>0.05$ ).

Figure 4 compares the average amount of R-phase present in ProFile files' Ni-Ti alloy as a function of temperature and the average number of cycles to fracture, as a function of temperature as well. The evolution of $\mathrm{N}_{\mathrm{f}}=\mathrm{f}(\mathrm{T})$ curve is noticeably comparable to the one that shows decay of R-phase upon heating.

Table 3. Number of cycles to fracture $\left(\mathrm{N}_{\mathrm{f}}\right)$ and length of fractured tip segment $\left(\mathrm{L}_{\mathrm{f}}\right)$

\begin{tabular}{|c|c|c|c|c|}
\cline { 2 - 5 } \multicolumn{1}{c|}{} & \multicolumn{4}{c|}{$\mathrm{N}_{\mathrm{f}} / \mathrm{L}_{\mathrm{f}}(\mathrm{mm})$} \\
\cline { 2 - 5 } \multicolumn{1}{c|}{} & $10^{\circ} \mathrm{C}$ & $20^{\circ} \mathrm{C}$ & $37^{\circ} \mathrm{C}$ & $65^{\circ} \mathrm{C}$ \\
\hline $\mathrm{n}$ & 12 & 12 & 12 & 12 \\
\hline Min. & $1770 / 10,6$ & $697,1 / 9,75$ & $577,7 / 10,25$ & $715 / 10,45$ \\
\hline Max. & $2533 / 14,5$ & $2343 / 14,15$ & $1730 / 13,8$ & $1273 / 13,8$ \\
\hline Average & $2235 / 12,14$ & $1498 / 12,03$ & $960,2 / 11,85$ & $1021 / 11,93$ \\
\hline St. Dev. & $237,5 / 1,345$ & $526 / 1,359$ & $370,1 / 1,06$ & $155,5 / 1,006$ \\
\hline
\end{tabular}

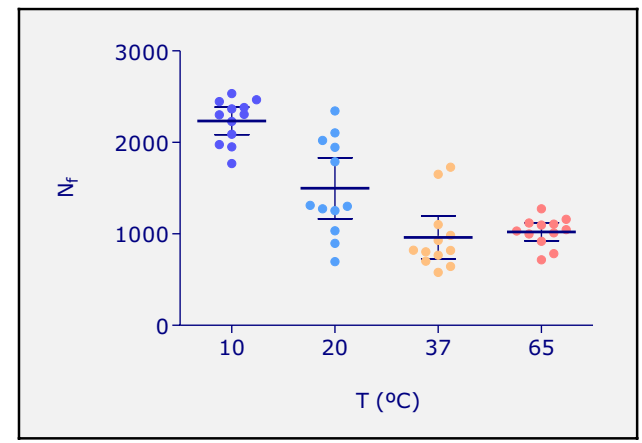

a) Number of cycles to fracture $\left(\mathrm{N}_{\mathrm{f}}\right)$

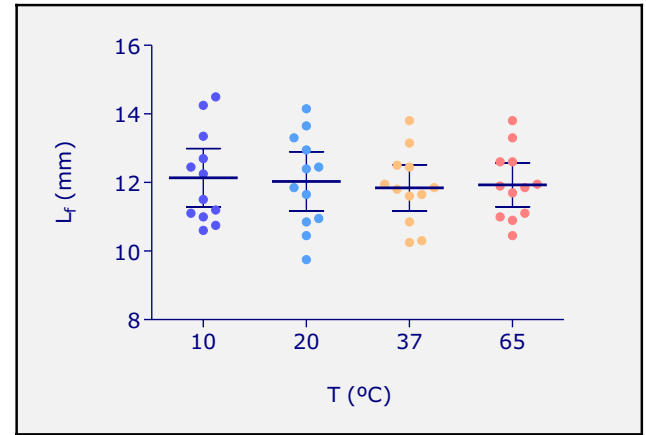

b) Length of fractured tip segment $\left(\mathrm{L}_{\mathrm{f}}\right)$

Fig. 3. Results for rotation/flexion assays 


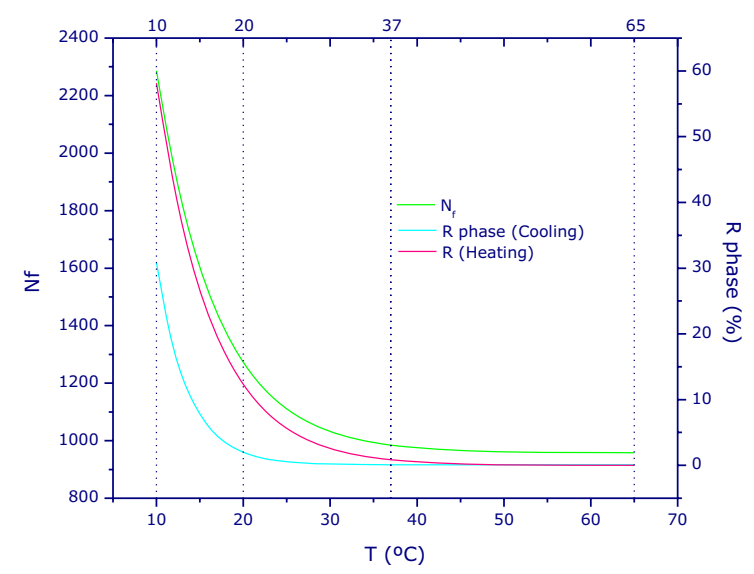

Fig. 4. Effect of temperature on R-phase percentage and on $\mathrm{N}_{\mathrm{f}}$

\section{Discussion}

Clinical conditions are best modeled by using endodontic files in extracted teeth [31, 32]. However, natural teeth are highly variable as far as internal morphology [32, 33] and dentin microhardness [34] are concerned. It is, thus, impossible to obtain homogeneous samples for testing Ni-Ti files [35]. A non-dental model was chosen as it allows for standardization of assay conditions and minimizes other mechanisms of file fracture other than cyclic fatigue [31]. All non-dental models published that are based on insertion of files in hollow curved tubes $[25,31,36]$ were excluded: if tubes are metallic, they do not allow for checking good adaptation of files to flexion arch; if they are made of glass, they do not allow for quick and reliable temperature control. The proposed prototype derived from one initially described by Gambarini [21] and by Haikel et al. [22]. It differs from theirs in the chosen radius of curvature (10 $\mathrm{mm}$ in the present study versus $5 \mathrm{~mm})$. Other authors [23, 24, 33,37 suggest $10 \mathrm{~mm}$ radius of curvature as a fairly good reproduction of the average endodontic canal found in everyday clinical setting. Another main difference in the present prototype is the cooling/heating system. Whereas all other authors [21-24, 33, 37] test files at room temperature and cool down any possible heat generated by friction by means of air spray, in this study the flexion is imposed on files by a testing platform of significant metal mass, cooled or heated by continuous water flow, which confers a highly thermal stability to the testing apparatus.

Control of testing temperature is of paramount relevance since structural state of Ni-Ti alloy depends on temperature, as shown by D.S.C. assays. These assays showed that a significant amount of R-phase is present in the alloy at temperatures not far below body temperature. It so happens R-phase Young modulus is smaller than that of austenite - this being the reason why Kuhn e Jordan [30] suggested Ni-Ti files that encompass B2 $\rightarrow \mathrm{R}$ transformation might be more flexible than others in which this transformation does not take place. Iijima et al. [30] used orthodontic wires with different $A_{f}$ temperatures to show that the more R-phase is present at a given temperature, the lower the superelastic plateau stress level in tensile tests.

In the present study, the possibility of increasing ProFile .06(35) files' lifespan through R-phase raise was under investigation. It was clearly shown that the number of cycles to fracture doubles by lowering test temperature from $37{ }^{\circ} \mathrm{C}$ to $10^{\circ} \mathrm{C}$, all other conditions remaining the same. This strongly correlates to the structural state of the Ni-Ti alloy, as R-phase is strongly present at $10{ }^{\circ} \mathrm{C}$ but insignificantly there at $37^{\circ} \mathrm{C}$. Further studies should be carried in order to verify these clinically promising results in other file brands.

\section{Acknowledgment}

The authors acknowledge FCT/MCTES for the pluriannual financial support of CENIMAT/I3N.

\section{References}

[1] Miyashita M, Kasahara E, Yasuda E, Yamamoto A, Sekizawa T. Root canal system of the mandibular incisor. J Endod. 1997 Aug;23(8):479-84.

[2] Willershausen B, Tekyatan H, Kasaj A, Marroquin BB. Roentgenographic in vitro investigation of frequency and location of curvatures in human maxillary premolars. J Endod. 2006 Apr;32(4):307-11. 
[3] Lee JK, Ha BH, Choi JH, Heo SM, Perinpanayagam H. Quantitative three-dimensional analysis of root canal curvature in maxillary first molars using micro-computed tomography. J Endod. 2006 Oct;32(10):941-5.

[4] Weiger R, ElAyouti A, Lost C. Efficiency of hand and rotary instruments in shaping oval root canals. J Endod. 2002 Aug;28(8):580-3.

[5] Caliskan MK, Pehlivan Y, Sepetcioglu F, Turkun M, Tuncer SS. Root canal morphology of human permanent teeth in a Turkish population. J Endodontics. 1995 Apr;21(4):200-4.

[6] Hata G-i, Uemura M, Kato AS, Imura N, Novo NF, Toda T. A comparison of shaping ability using ProFile, GT file, and Flex-R endodontic instruments in simulated canals. J Endod. 2002 Apr;28(4):316-21.

[7] Sonntag D, Delschen S, Stachniss V. Root-canal shaping with manual and rotary Ni-Ti files performed by students. Int Endod J. 2003 Nov;36(11):715-23.

[8] Schafer E, Lohmann D. Efficiency of rotary nickel-titanium FlexMaster instruments compared with stainless steel hand K-Flexofile--Part 2. Cleaning effectiveness and instrumentation results in severely curved root canals of extracted teeth. Int Endod J. 2002 Jun;35(6):514-21.

[9] Peters OA, Laib A, Gohring TN, Barbakow F. Changes in root canal geometry after preparation assessed by high-resolution computed tomography. J Endodon. 2001 Jan;27(1):1-6.

[10] Dalton BC, Orstavik D, Phillips C, Pettiette M, Trope M. Bacterial reduction with nickel-titanium rotary instrumentation. J Endod. 1998 Nov;24(11):763-7.

[11] Coldero LG, McHugh S, MacKenzie D, Saunders WP. Reduction in intracanal bacteria during root canal preparation with and without apical enlargement. Int Endod J. 2002 May;35(5):437-46.

[12] Zehnder M. Root canal irrigants. J Endod. 2006 May;32(5):389-98.

[13] Weiger R, Bruckner M, ElAyouti A, Lost C. Preparation of curved root canals with rotary FlexMaster instruments compared to Lightspeed instruments and NiTi hand files. Int Endod J. 2003 Jul;36(7):483-90.

[14] Schafer E, Schulz-Bongert U, Tulus G. Comparison of hand stainless steel and nickel titanium rotary instrumentation: a clinical study. J Endod. 2004 Jun;30(6):432-5.

[15] Pettiette MT, Conner D, Trope M. Procedural Errors With the Use of Nickel-Titanium Rotary Instruments in Undergraduate Endodontics. J Endod 2002:259.

[16] Leseberg DA, Knowles K, Hammond NB. Clinical incidence of endodontically treated teeth with nonretrievable rotary files

1564. J Dent Res. 2005;84 (Spec Iss A):abstract.

[17] Di Fiore PM, Genov KI, Komaroff E, Dasanayake AP, Lin L. Fracture of ProFile nickel-titanium rotary instruments: a laboratory simulation assessment. Int Endod J. 2006 Jun;39(6):502-9.

[18] Iqbal MK, Kohli MR, Kim JS. A retrospective clinical study of incidence of root canal instrument separation in an endodontics graduate program: a PennEndo database study. J Endod. 2006 Nov;32(11):1048-52.

[19] Spili P, Parashos P, Messer HH. The impact of instrument fracture on outcome of endodontic treatment. J Endod. 2005 Dec;31(12):845-50.

[20] Parashos P, Messer HH. Rotary NiTi instrument fracture and its consequences. J Endod. 2006 Nov;32(11):1031-43.

[21] Gambarini G. Torsional and cyclic fatigue testing of ProFile NiTi rotary instruments. Smile J Evolut Dent online (wwwdental-smilecom) 1999;1:4-14

[22] Haikel Y, Serfaty R, Bateman G, Senger B, Allemann C. Dynamic and cyclic fatigue of engine-driven rotary nickel-titanium endodontic instruments. J Endod. 1999 Jun;25(6):434-40.

[23] Gambarini G. Cyclic fatigue of nickel-titanium rotary instruments after clinical use with low- and hightorque endodontic motors. J Endod. 2001 Dec;27(12):772-4.

[24] Fife D, Gambarini G, Britto Lr Lr. Cyclic fatigue testing of ProTaper NiTi rotary instruments after clinical use. Oral Surg Oral Med Oral Pathol Oral Radiol Endod. 2004 Feb;97(2):251-6.

[25] Pruett JP, Clement DJ, Carnes DL, Jr. Cyclic fatigue testing of nickel-titanium endodontic instruments. J Endod. 1997 Feb;23(2):77-85.

[26] Torrisi L. The NiTi superelastic alloy application to the dentistry field. Biomed Mater Eng. 1999;9(1):3947.

[27] Brantley WA, Svec TA, Iijima M, Powers JM, Grentzer TH. Differential scanning calorimetric studies of nickel titanium rotary endodontic instruments. J Endod. 2002 Aug;28(8):567-72.

[28] Brantley WA, Svec TA, Iijima M, Powers JM, Grentzer TH. Differential scanning calorimetric studies of nickel-titanium rotary endodontic instruments after simulated clinical use. J Endod. 2002 Nov;28(11):774-8.

[29] Alexandrou GB, Chrissafis K, Vasiliadis LP, Pavlidou E, Polychroniadis EK. SEM observations and differential scanning calorimetric studies of new and sterilized nickel-titanium rotary endodontic instruments. J Endod. 2006 Jul;32(7):675-9.

[30] Kuhn G, Jordan L. Fatigue and mechanical properties of nickel-titanium endodontic instruments. J Endod. 2002 Oct;28(10):716-20. 
[31] Yao JH, Schwartz SA, Beeson TJ. Cyclic fatigue of three types of rotary nickel-titanium files in a dynamic model. J Endod. 2006 Jan;32(1):55-7.

[32] Hulsmann M, Gressmann G, Schafers F. A comparative study of root canal preparation using FlexMaster and HERO 642 rotary Ni-Ti instruments. Int Endod J. 2003 May;36(5):358-66.

[33] Young JM, Van Vliet KJ. Predicting in vivo failure of pseudoelastic NiTi devices under low cycle, high amplitude fatigue. J Biomed Mater Res B Appl Biomater. 2005 Jan 15;72(1):17-26.

[34] Guelzow A, Stamm O, Martus P, Kielbassa AM. Comparative study of six rotary nickel-titanium systems and hand instrumentation for root canal preparation. Int Endod J. 2005 Oct;38(10):743-52.

[35] Kaptan F, Sert S, Kayahan B, Haznedarolu F, Tanalp J, Bayirli G. Comparative evaluation of the preparation efficacies of HERO Shaper and Nitiflex root canal instruments in curved root canals. Oral Surg Oral Med Oral Pathol Oral Radiol Endod. 2005 Nov;100(5):636-42.

[36] de Castro Martins R, Bahia MGA, Buono VTL, Horizonte B. The effect of sodium hypochlorite on the surface characteristics and fatigue resistance of ProFile nickel-titanium instruments. Oral Surg Oral Med Oral Pathol Oral Radiol Endod. 2006 Oct;102(4):e99-105.

[37] Peters OA, Barbakow F. Dynamic torque and apical forces of ProFile.04 rotary instruments during preparation of curved canals. Int Endod J. 2002 Apr;35(4):379-89. 